Spatial distribution of

tuberculosis and relationship

with living conditions in an

urban area of Campina Grande -

2004 to 2007

\section{Distribuição espacial da tuberculose e a relação com condições de vida na área urbana do município de Campina Grande - 2004 a 2007}

\section{Abstract}

This research aimed to study the spatial distribution of tuberculosis and its relationship with living conditions in the urban area of the city of Campina Grande in the period from 2004 until 2007. It is an ecologic study which used the city's neighborhood distribution; demographic, social and economic data from year 2000 census; and the new cases of tuberculosis reported to the Disease and Reporting Information System. Georeferencing was done for the cases of tuberculosis, and disease incidence was calculated by neighborhood. Rates were softened and the Global Moran Index was calculated. Social-economic data were grouped in quartiles according to the Life Condition Index, calculating the incidence of TB in each stratum of living conditions. The results showed that the spatial distribution of tuberculosis in the city is not uniform. Grouping neighborhoods according to the Life Conditions Index revealed social differences that can justify the occurrence of higher incidence rates in the most socially and economically vulnerable regions. The best living condition stratum presented a high incidence possibly due to the underreporting of the cases of tuberculosis caused mainly by the centralization of disease control services. We hope that this study may help outline control strategies for the city of Campina Grande, from the perspective of health promotion, for a disease so socially determined, as is the case of TB.

Keywords: Tuberculosis. Incidence. Life conditions. Spatial distribution. 


\section{Resumo}

A pesquisa objetivou estudar a distribuição espacial da tuberculose e a sua relação com condições de vida na área urbana do município de Campina Grande no período de 2004 a 2007. Trata-se de um estudo ecológico que utilizou a malha dos bairros do município; dados demográficos, sociais e econômicos do censo 2000; e os casos novos de tuberculose notificados no Sistema de Informação de Agravos e Notificação. Realizou-se o georeferenciamento dos casos de tuberculose e calculou-se a taxa de incidência da doença por bairro. Foi feita suavização das taxas e calculado o Índice de Moran Global. Os dados socioeconômicos foram agrupados em quartis segundo o Índice de Condições de Vida e calculou-se a incidência da tuberculose em cada estrato de condições de vida. Os resultados mostram que a distribuição espacial da tuberculose na cidade não é uniforme. $\mathrm{O}$ agrupamento dos bairros de acordo com o Índice de Condições de Vida revelou diferenças sociais que podem justificar a ocorrência das maiores taxas de incidência nas regiões social e economicamente mais vulneráveis. $\mathrm{O}$ estrato de melhor condição de vida apresentou elevada incidência, possivelmente devido à subnotificação dos casos de tuberculose causada principalmente pela centralização do serviço de controle da doença. Espera-se que este estudo possa subsidiar o delineamento das estratégias de controle no município de Campina Grande, na perspectiva da promoção da saúde, de uma doença tão caracteristicamente de determinação social como a TB.

Palavras-chave: Tuberculose. Incidência. Condições de vida. Distribuição espacial.
Introduction

The tuberculosis (TB) is one of the infectious diseases with relevant importance in the profile of morbidity in Brazil ${ }^{1}$. In 2009 Brazil was scored $19^{\text {th }}$ among the 22 countries responsible for $80 \%$ of the total of cases of Tuberculosis (TB) notified in the world, presenting in that year the notification of 75.040 cases of the disease, corresponding to an incidence rate of 45 cases in 100.000 inhabitants, mortality rate of 2,1 of the cases in 100.000 inhabitants and a proportion of co-infection TB/HIV of $22 \%^{2}$.

In the Estate of Paraíba, 1.042 cases of TB were notified in 2009, representing an incidence rate of 27,6 cases for all the forms/100.000 inhabitants ${ }^{3}$. In cities of João Pessoa and Campina Grande, biggest urban centers of the Estate concentrate the highest charges of morbidity of the TB.

Campina Grande, one of the priority cities for the program of Control of TB in the Estate of Paraíba, adopted the DOTS (Direct Observed Treatment Short-Course) as strategy for the control of the disease ${ }^{4}$.

This city presented an oscillatory behavior of the incidence rate of the TB in the period from 2004 to 2007. It is observed an increase of the rate from 42 to 46 cases of TB in 100.000 inhabitants in the period from 2004 to 2005 , followed by a strong reduction for 29 cases of TB in 100.000 inhabitants in the year of 2006, accompanied by an elevation of the rate for 33 cases of TB in 100.000 inhabitants in 2007. In this period, there was an increase in the percentage of cure of the disease, from $76,0 \%$ in 2004 to $77,2 \%$ in 2007 respectively 3 .

This research was developed in the city of Campina Grande and had the hypothesis that there is relation between life conditions of the population and the distribution of the disease in the territory mentioned, of said in a different form, that the social inequalities determine differentiated situations of access to the services dnd distinct levels of health of a population.

It conveys to emphasize that in this study the comprehension of social inequality 
is anchored in the social theory and in the theory of the life style, once that people consider "the patterns of health and disease as the biological consequences of the styles of live and own works of each social group, determined by the economic organization and by the political priorities of the society ${ }^{5}$."

According to the world health organization $(\mathrm{WHO})^{6}$, in the world the bad organization of the Programs of Control of the TB (PCT), the poverty, the growth of the population, the migration and the meaningful increase of the cases in regions with high prevalence of the Virus of the Human Immunodeficiency Virus (HIV) justify the persistence of the $\mathrm{Tb}$ as a great problem of public health.

Among these factors, we highlight the life conditions that influence decively so that the disease keep on endemic in our country, threatening the life of the citizens socialy more vulnerable. Teixeira ${ }^{7}$ highlights the importance of the association of the TB with the precarious social-economic conditions, being this disease directly associated to the conditions of the environment.

The TB, as a social problem, must be studied under a micro regional view, local and focal, according to the approach of the spatial distribution ${ }^{7}$.

Hino $^{8}$ ensures that in Brazil very little is known about the spatial distribution of the endemic diseases, like the TB, in urban areas. The author also says that the information about the spatial and time diffusion of these diseases allows understanding the occurrence of these events in the territory. Besides this, the description and view of the spatial distribution of the event make possible to identify its association with local features like the social-economic conditions.

From what was exposed, this study aims to analyze in the period from 2004 until 2007 the spatial distribution of the TB in the urban area of the city of Campina Grande and its relation with the life conditions of the population.

\section{Methodology}

The study developed in this research is type ecologic. According to Rouquayrol ${ }^{9}$, the ecologic study compares global features with the relation between conditions of life and health.

The city of Campina Grande is located in the middle region of the Agreste of Paraíba. It has $620,6^{\mathrm{sm}}$ of total area, with urban area of $98^{\mathrm{sm}}$ divided in 50 neighborhoods, and population of 381.422 inhabitants $^{10}$.

In the elaboration of the study the digital maps of the neighborhoods of Campina Grande obtained in the Secretaria de Planejamento of the city (SEPLAN) were used. The data of the new cases of TB were extracted of the System of Information of Grievances and Notification (SINAN), of the data bank of the Health Ministry. Demographic and social economic data were obtained from the Censo 2000 of the Instituto Brasileiro de Geografia e Estatística $(\mathrm{IBGE})^{11}$.

In this investigation the following softwares were used: Stata 9.0 ${ }^{12}$, Google Earth ${ }^{13}$ and the System of Geographic Information (SGI) ArcView 3.1 ${ }^{14}$. The applicative Stata was used to calculate the incidence rates of TB by neighborhood of Campina Grande and to calculate the index of life conditions. (ILC). The Google Earth was used to geo reference (geo codify) the cases of TB. The equipment GPS (Global Positioning System) was used to geo reference the users which address were not located on the Google Earth. In the SGI the procedures of accounting of the cases of TB by neighborhood, calculation of the measure of spatial self correlation and mapping of the epidemiologic and social economic indicators were performed.

In the city of Campina Grande, in the period from 2004 until 2007, were notified in the SINAN 601 new cases of TB. In the evaluation of this bank were detected 5 cases duplicated, 3 cases without information of the address of residence of the user (without geo referencing) and 16 cases non residents in the urban zone of Campina Grande. These 
cases were excluded from the data analyzis.

The population of the urban are of the city in the period from 2004-2007, used in the calculation of the incidence rate by neighborhood, was obtained from the population of the census 2000 increased by the annual rate of population growth of the city of $1,15 \%$.

Rates calculated based on small population accountings, like in the case of the neighborhoods, can present problems related to the excessive random floating of their values. To minimize these problems, the transformation of Freeman-Tukey was used to calculate the rate of incidence of the TB. This transformation was used by researchers such as Cerbino Neto ${ }^{15}$ to stabilize the variance of the rates and is calculate as it follows:

$T x=\sqrt{\left[\left(\frac{\# \text { cases TB }}{\text { population }}\right) * 100000\right]}+\sqrt{\left\{\left[\frac{(\# \text { cases } T B+1)}{\text { population }}\right] * 100000\right\}}$

With this calculation values were attributed to all the neighborhoods and the calculation of the square root of incidence resulted in soften annual rates by reduction of the variance of their values. Thematic map with classes defined by "natural breaks" that take into consideration the variance present in the group of values in the determination of the intervals of the data, this method separates better the different attributes and aggregate the similars ${ }^{14}$. These maps were used to better highlight the patterns of distribution of the TB.

The index of Moran of the rates of incidence of the TB was also calculated. This index is used to characterize the spatial dependence, showing how the values are correlated in the space. The basic idea is to estimate how much the observed value of an attribute in a region is dependent of the values of this same variable in the neighbor locations ${ }^{16}$.

The I of Moran is calculated as it follows:

$$
\mathrm{I}=\frac{\sum_{i=l}^{n} \sum_{j=l}^{n} w_{i j}\left(z_{i}-\bar{z}\right)\left(z_{j}-\bar{z}\right)}{\sum_{i=l}^{n}\left(z_{i}-\bar{z}\right)^{2}}
$$

In the above equation, $n$ is the number of areas, $z i$ is the value of the attribute considered in the area $i, z$ is the average value of the attribute in the region of study and wij the elements of the matrix normalized of spatial proximity, which expresses the structure of the spatial neighborhood of data. The Index of Moran is used for a test which null hypothesis is of spatial dependence; in this case, its value is zero. Positive values (between 0 and +1 ) indicate direct correlation and negative (between 0 and - 1 ) inverse correlation ${ }^{16}$.

The social-economic characteristics of the demographic census of 2000 were synthesized in an adaptation of the ICV elaborated by Paim et al. ${ }^{17}$. The ICV uses five indicators related to the characteristics of life conditions: a) proportion of family leaders in permanent particular households with monthly average income equal or inferior to two minimum salaries (INCOME), b) proportion of literate people from 10 to 14 (EDUC), c) percentage of houses in subnormal agglomerate related with the total of households (COMMUNITY), d) reason between the average number of people living in a household and the average number of rooms with function of bedroom, e) percentage of households with internal pipes linked to the global services of water supply (SANEA).

In the Census of 2000 there are no allusive data to the average number of rooms used as dormitories by neighborhood. Thus, it was not possible to calculate the reason between the average number of people living in each household and average number of rooms used as dormitories, being considered only the average number of people living in each household as the indicator for the composition of the ICV.

These measures were calculated for each neighborhood of Campina Grande. The indicators INCOME, COMMUNITY and average number of dwellers were disposed in increasing order, the EDUC and the SANEA in decreasing order, considering the average value of each one of them in each neighborhood. After that, each one received a scoring 
related to the number in crescent order of the neighborhood. Afterwards the sum of this score was made for the five indicators of each neighborhood, obtaining as result the ICV (smaller value than 17 and bigger, 201). Smaller values of ICV correspond to better live conditions.

These values were grouped in quartiles to classify the neighborhoods by stratus of live conditions: better (ICV from 15 to 62), regular (ICV from 65 to 96), bad (ICV from 103 to 144) and worse (ICV from 146 to 201). Thematic map of the ICV with classes formed by quartiles was compared with the map of incidence of TB in the city. The rates of incidence of TB for the stratus were also calculated, aiming to evaluate the variation of the incidence of TB among social-economic groups.

This research was approved by the Committee of Ethic in Research (CER) of the Universidade Federal da Paraíba and had a report emitted in July 2008, under the protocol number 0274 .

\section{Results}

537 cases of TB corresponding to $93 \%$ of all the new cases resident in the urban zone of Campina Grande from 2004 to 2007 were geo referred.

The analysis of the index of Moran for the incidence rate of the TB highlighted a positive autocorrelation among the neighborhoods of Campina Grande in all the period studied. However, the autocorrelation did not present statistic significance for the year of 2005 (value of $p=0,57$ ) and for the rate of the period from 2004 to 2007 (value of $p=0,18$ ). Therefore, it can be said for the years of 2004 (Moran = 0,15 and value of $p$ $=0,03), 2006$ (Moran $=0,17$ and value of $p=$ $0,02)$ and 2007 (Moran $=0,16$ and value of $\mathrm{p}=$ $0,02)$ that there is a positive autocorrelation, given that the value of the Index of Moran found was bigger than zero; this means that there is a relation of spatial dependence with tendency of neighbor neighborhoods presenting similar incidence rates.

The map of the distribution of the soften rate of incidence of the TB in the period from 2004-2007 in the neighborhoods of the urban area of the city of Campina Grande (picture 1) presents a pattern of distribution well defined with the presence of an agglomeration formed by eight neighborhoods between the neighborhood Centro and neighborhoods of the region north and east which present rates that represent a bigger vulnerability for the TB. We also call attention the fact that most of the neighborhoods are in a condition of transition between smaller and bigger vulnerability for the $\mathrm{TB}$, being these locations spatially distributed in the regions north, south, east and central of the urban area of the city. The neighborhoods Serrotão, Universitário and Distrito Industrial are isolated with high rate of incidence of TB.

The maps of the softened incidence of the TB in the years from 2004 to 2007 (Picture 2) indicate that the spatial distribution of the TB in the urban area of the city of Campina Grande is not uniform, with tendency of concentration of higher rates in some neighborhoods, fact that reveals the heterogeneity of the occurrence of the disease in the city with the presence of spatial agglomeration in the central zone. In the years in which reduction was observed of the incidence, there was a reduction of the rates of the central region and east. Although the neighborhoods of the west region, suffered a bigger reduction of rates, except for the neighborhood Serrotão. The neighborhoods of the south zone also have a reduction of the incidence rate in the period analyzed, highlighting the neighborhoods Velame and Distrito Industrial.

The Map of the ICV (Picture 3) shows that the neighborhoods with the best life conditions for an agglomeration between the central neighborhood and the adjacent ones which are extended to the regions south east and southwestern of the city. It can be seen that the life conditions get worse as people get farther from the central region, reaching the worst indexes in the neighborhoods of the extreme east, north and south. The neighborhoods classified with 


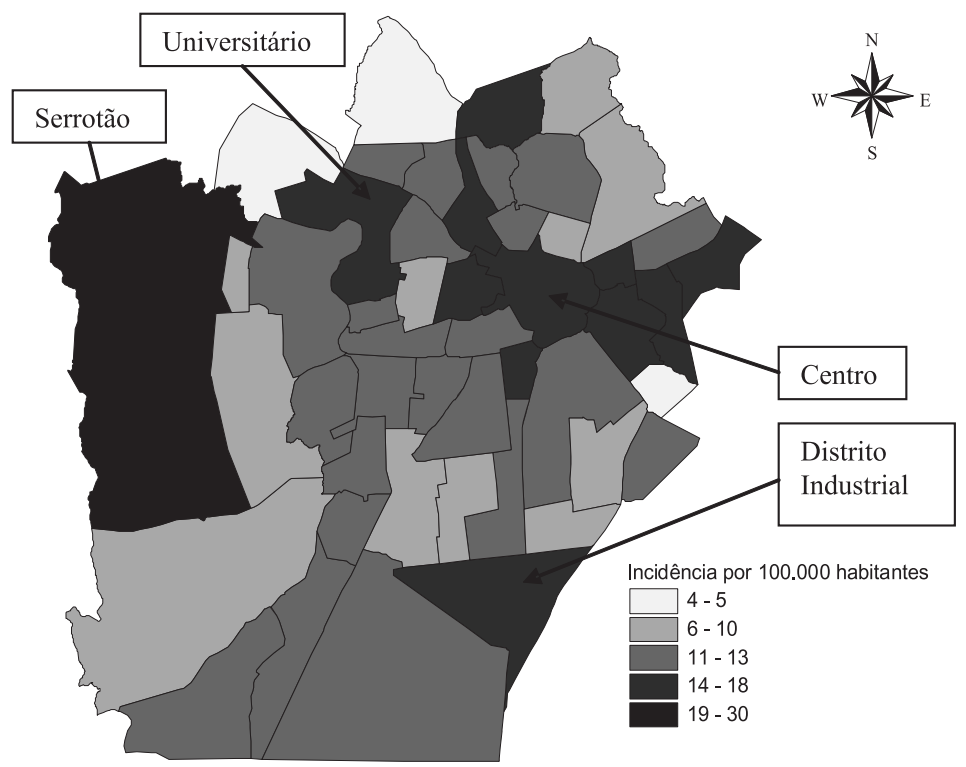

Source / Fonte: SEPLAN/Campina Grande, SINAN, IBGE

Figure 1 - Map of the urban area of Campina Grande, according to the incidence rate of TB smoothed by the transformation of Freeman-Tukey by neighborhood, 2004-2007.

Figura 1 - Mapa da área urbana do município de Campina Grande, segundo taxa de incidência da TB suavizada pela transformação de Freeman-Tukey por bairro, 2004-2007.

regular life conditions are located between the central neighborhood region and the extremes, east, west, north and south, close either to high and low conditions of life. it also calls the attention the occurrence of neighbor neighborhoods with very different ICV, as observed between the neighborhoods Mirante and Monte Castelo and between Jeremias and Palmeira. The Pedregal, neighborhood classified with the worst life condition, appears as the only neighborhood situated in the surroundings of the central region of the urban area of the city.

The average rates of incidence of TB in the stratus of conditions of life indicate that bigger incidences are focused on the neighborhoods of stratus with worse ICV. A bigger difference of rates between the stratus of regular and worse life condition is realized, when the rate of the neighborhoods with worse ICV has an increase of $86 \%$ related to the rate of incidence of the stratus of regular condition (Picture 4).

Although the differential observed of the effect of the ICV, it was expected that the rate of incidence of the disease was bigger in the sense of the stratus of worse life conditions, forming a gradient of increase in the stratus. What is observed, though, when this indicator is analyzed in the period studied, is that there is a gradient only in the stratus of regular, of bad and worse life condition.

The neighborhoods Centro, Prata and Palmeira, which belong to the stratus of best life condition, present higher values of the rate of incidence of the TB and were determinant for the non occurrence of the gradient expected.

\section{Discussion}

It is important to highlight that the analysis of the information about the incidence of the TB presented in this research must be done with caution, as this rate is based on the number of registers of TB in the SINAN, which information are subjected to variations facing the problems that involve the systems of information in health in the country. It is known that the world registers of the TB are sub notified and reach, about, the half of the estimated by the OMS ${ }^{18}$. 


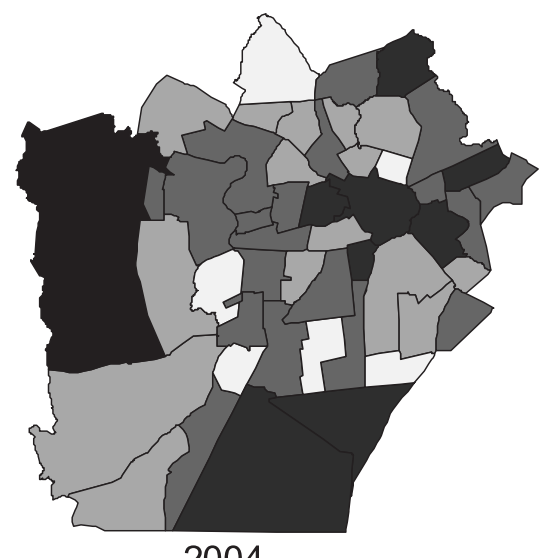

2004

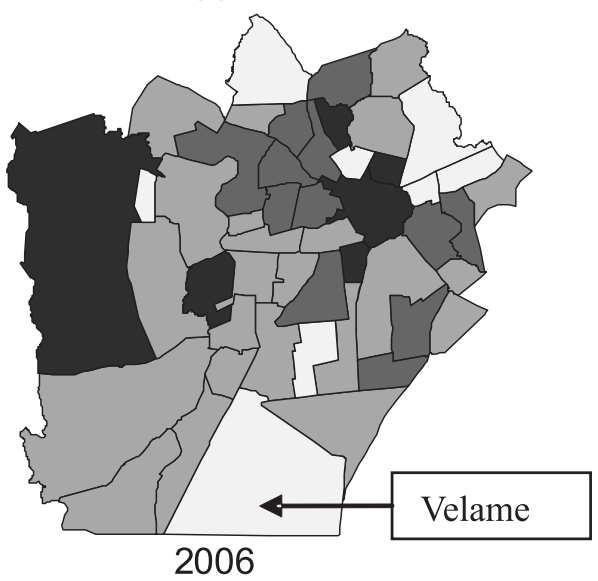

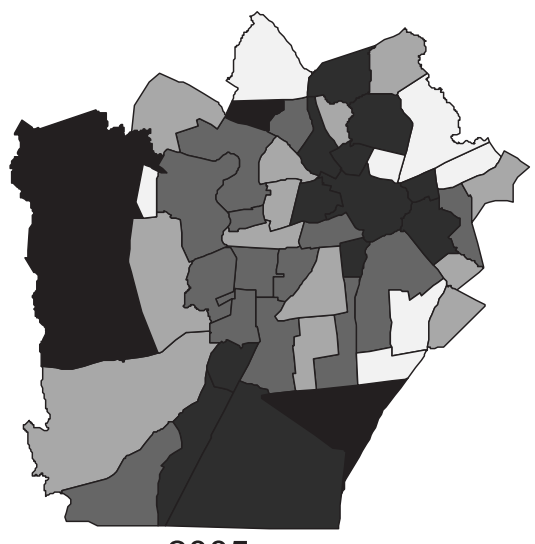

2005

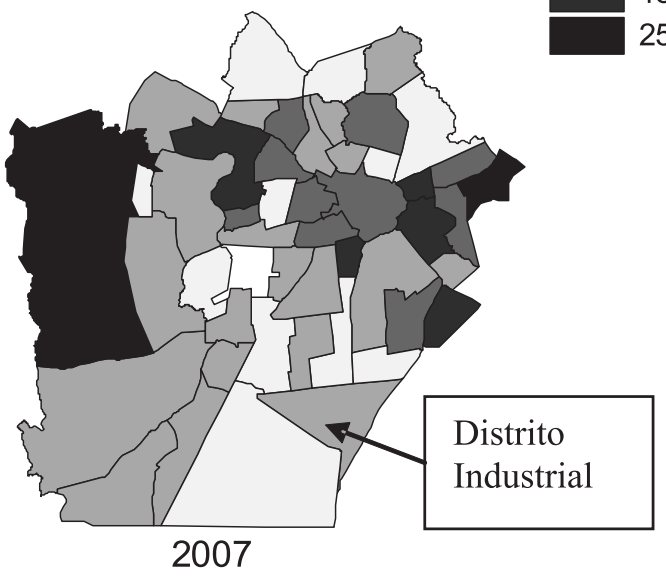

Incidência por 100.000 hab

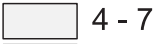

$8-12$

$13-17$

$18-24$

$25-34$

Source / Fonte: SEPLAN/Campina Grande, SINAN, IBGE

Figure 2 - Map of the urban area of Campina Grande, according to incidence rate of TB smoothed by the transformation of Freeman-Tukey by district, from 2004 to 2007.

Figura 2 - Mapa da área urbana do município de Campina Grande, segundo taxa de incidência da TB suavizada pela transformação de Freeman-Tukey por bairro, 2004 a 2007.

Hence the interpretation has to be careful, because the quality of data depends on the search system of cases and registers of each region ${ }^{19}$.

The distribution of the rates of incidence of TB is characterized by the concentration of higher rates in the neighborhoods of the central and east region of the city. These neighborhoods are characterized for being populated and with high demographic densities. These characteristics can explain partially why the variations of the incidence in the city are strongly influenced by the variation of the incidence of these neighborhoods during the years studied.

The indicators composed with the ICV can be understood as an average that associates different social economic and environmental characteristics in one synthetic indicator to analyze the characteristics of the population groups living in certain geographic areas ${ }^{20}$. When such indexes are used as referential for the description of the geographic areas, we assume to be detecting the interaction of several factors in the determination of the quality of life of a specific area.

The distribution of the life conditions of the population of Campina Grande follows the standards of inequality observed in the big urban centers. According to Vendramini ${ }^{21}$ this pattern is characterized by a periphery doted of basic urban infrastructure and occupied by people of low income 


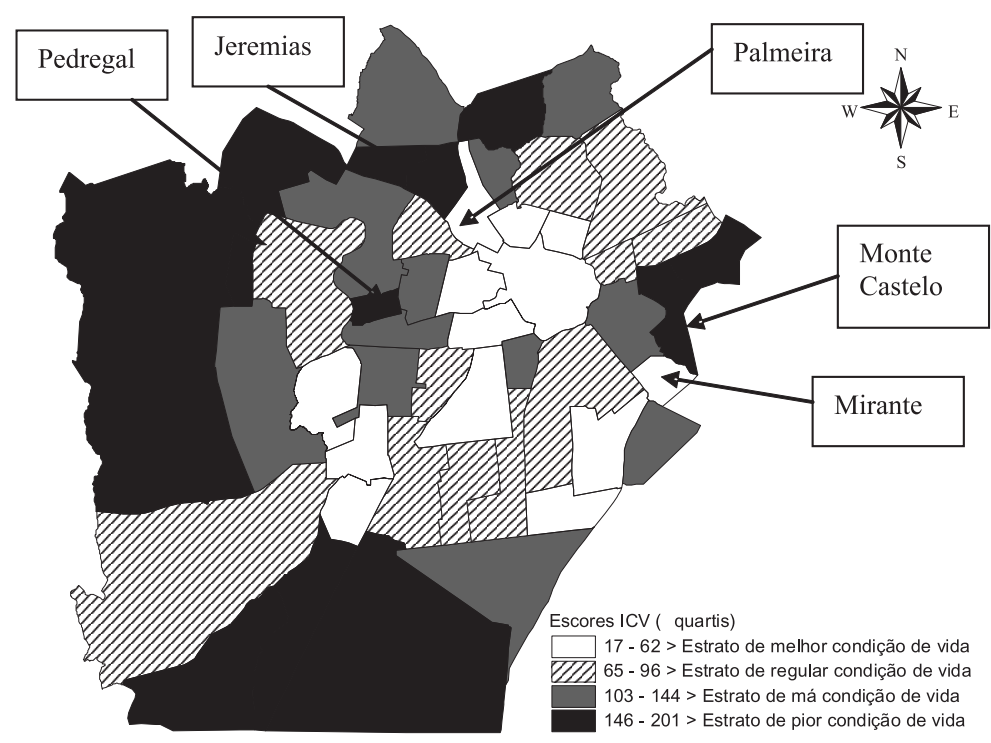

Source / Fonte: SEPLAN/Campina Grande, IBGE

Figure 3 - Map of the urban area of Campina Grande, neighborhoods by Living Condition Index (quartile), 2000.

Figura 3 - Mapa da área urbana do município de Campina Grande, bairros segundo Índice de Condições de Vida (quartil), 2000.

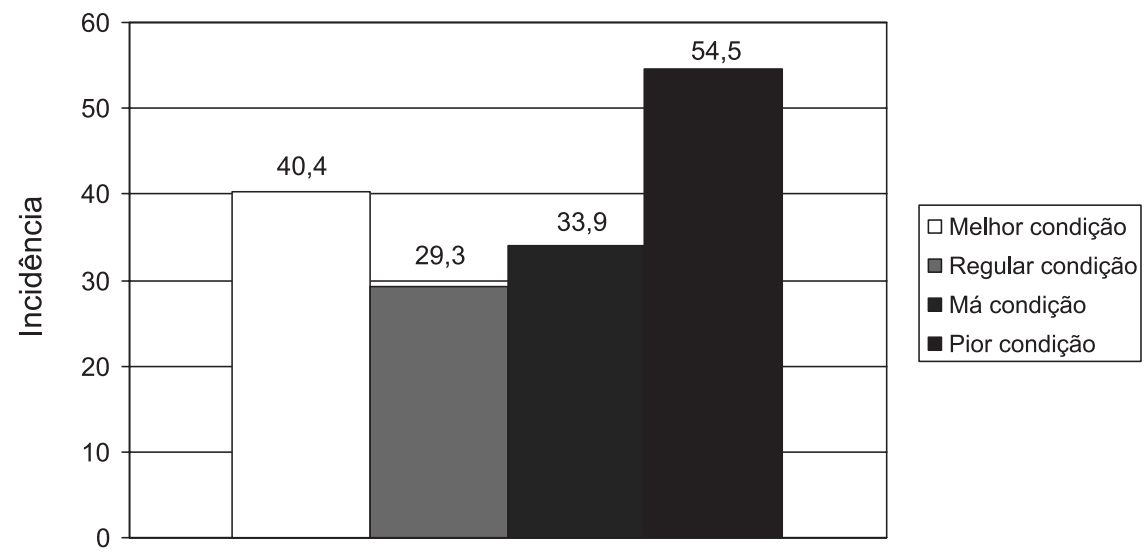

Estrato ICV

Source / Fonte: SINAN, IBGE

Figure 4 - Incidence rate of TB per 100,000 inhabitants in each living condition strata of the urban area of Campina Grande, 2004-2007.

Figura 4 - Taxa de incidência da TB por 100000 habitantes nos estratos do ICV da área urbana do município de Campina Grande, 2004-2007.

with worse life conditions. There is also in this pattern areas with access to the urban facilities, occupied by groups of high income who live in adequate residences and with better patterns of health.

The concept of territory or space surpasses its physical or natural condition and recovers its historical and social character. Therefore, the study of the life conditions, according to the spatial insertion of the human groups in the territory, tends to be a theoretical-methodological alternative for the analysis of the necessities and social inequalities of the health ${ }^{22}$. In the urban 
area of the city of Campina Grande, by the analysis of the ICV, was possible to visualize the areas of better and worse life condition, revealing priority homogeneous groups for the formulation of specific actions.

However, the stratus of better condition of life had a very high incidence rate, higher than the stratus of regular and bad condition. Thus, the neighborhoods that form the stratus of better life condition can have other determinant factors for the high incidence of the TB.

Aiming to find answers for the results and for the high rate of incidence of the $\mathrm{TB}$ in the neighborhoods of the Centro, Prata and Palmeira, some hypothesis was taken into consideration. The first one was that the high rate in the three neighborhoods above mentioned was caused by the floating of the indicator rate of incidence determined by the small population present in these neighborhoods. However, it was checked that these neighborhoods do not have so small population that explain the abrupt variation in the incidence.

Another question taken into consideration is concerned to the sub notification of the cases of TB. In the city of Campina Grande, the event was pointed by Lima in the period from 2000 to $2006^{23}$. Among the determinant factors for this sub notification, we can infer the organization of the health service.

The service of control of the TB in the city of Campina Grande works in a centralized and deficient form ${ }^{24}$. According to Oliveira $^{25}$, the Service of Reference is located in the stratus of better life condition, which facilitates the access for the users of this stratus and makes difficult the access of the users of the stratus of worse conditions of life, as the users with smaller income and that need the transportation to arrive in the reference service. The study of Oliveira also showed that the professionals of the HFT do not know the cases of TB of the coverage territory.

These factors can have determined the sub notification of the cases of TB in the neighborhoods of the periphery and a possible capitation of cases in the neighborhoods of the central zone of the city, mainly in the neighborhoods of Centro, Prata and Palmeira. Besides this, the population agglomeration of these neighborhoods can result in the occurrence of a bigger number of cases of TB, which, therefore, can explain the high index of incidence of the disease in the stratus of better life condition.

Based on what was exposed and in our results we can infer for the urban area of the city of Campina Grande that, the worse the life condition the bigger will be the rate of incidence of TB (except for the neighborhoods of better life condition).

The analysis of the conditions of life indicates the perverse forms of social reproduction in a space where it was possible to present results that reveal a bigger penalty of the resident populations in neighborhoods with low social economic conditions. The influence of the life conditions in the incidence of the TB is described by RuffinoNetto ${ }^{26}$ like: "The society does not behave as a homogeneous set of individuals either they being virgins of infection or infected. In the process of production and reproduction inside the social classes the life conditions are unequal taking to different levels of density of agglomeration of people at work, in means of transportation and, in the places of living, which will create diverse possibilities of meetings where there will be possibility of transmission of TB".

According to Santos et al. ${ }^{27}$, the seriousness and the negative impact of the TB varies in the inverse reason of the Index of Human Development (IHD). The distribution of the disease is influenced by factors such as the territorial extension, the chaotic population growth and the concentration of people in the peripheries.

The results obtained allowed to identify homogeneous geographic areas where the dwellers share similar life conditions. For Chiesa $^{28}$ the identification of these homogeneous areas can make possible the choice of strategies and specific interventions for the necessities of their dwellers, as well as the prioritizing of the resources, contributing 
to reduce the inequalities in health. Like the TB is a disease recognized as of social determination, facing it cannot be reduced to typical procedures of the bacteriological focus, mainly today when the social inequality is deeper. Therefore, only the guarantee of medication and the observation of the consumption of the medicine are not sufficient actions to control $\mathrm{it}^{29,30}$.

Considering the magnitude of the TB as a disease that is socially produced, it is clear the necessity of bigger involvement of the managers and health professionals of health in implementing actions to transform the worrying

Picture of the disease in the urban area of the city of Campina Grande. So, we hope that this study provides this understanding and that data generated can subside the lining of the strategies of control, in the perspective of the promotion of health and of the life quality, of a so characteristic disease of social determination such as the TB.

\section{References}

1. Barata RB. Condições de saúde da população brasileira. In: Giovanella L; Scorel S, Lobato LVC et al. (orgs). Políticas e Sistema de Saúde no Brasil. Rio de Janeiro: Fiocruz; 2008. p. 167-213.

2. World Health Organization. Global tuberculosis control. WHO Report 2010. Geneva; 2010.

3. SINAN - Sistema de Informação de Agravos de Notificação. Disponível em http://dtr2004.saude.gov.br/ sinanweb/novo. [Acessado em 22 de janeiro de 2010]

4. Sá LD, Figueiredo TMRM, Lima DS, Andrade MN, Queiroga RPF, Cardoso MAA et al. A experiência da implantação do DOTS em seis municípios paraibanos. In: Ruffino Netto A, Villa TCS. Tuberculose - Implantação do DOTS em algumas regiões do Brasil: histórico e peculiaridades regionais. Ribeirão Preto: FMRP/REDE TB-USP; 2006. p. 142-65.

5. Barata RB. Como e porque as desigualdades sociais fazem mal à saúde. Rio de Janeiro: Fiocruz; 2009. p. 19-20.

6. World Health Organization. The global Plan to Stop TB 2006-2005. WHO Report. Geneve; 2006.

7. Teixeira GM. Aprofundar o conhecimento espacial da tuberculose para melhor combatê-la. Boletim de pneumologia sanitária 2004; 12(3): 141-43.

8. Hino P. Distribuição espacial dos casos de tuberculose no município de Ribeirão Preto nos anos de 1998 a 2002 [dissertação de mestrado]. Ribeirão Preto: Escola de Enfermagem da USP; 2004.

9. Rouquayrol MZ, Almeida Filho N. Epidemiologia e saúde. Rio de Janeiro: MEDSI; 1999.

10. IBGE - Instituto Brasileiro de Geografia e Estatística Estimativas da população para $1^{\circ}$ de julho de 2008. Disponível em http://www.ibge.gov.br. [Acessado em 15 de dezembro de 2008].
11. IBGE - Instituto Brasileiro de Geografia e Estatística. Censo Demográfico 2000: agregado por setores censitários dos resultados do universo. $2^{\text {a }}$ ed. Rio de Janeiro; 2003. Disponível em http://www.ibge.gov.br. [Acessado em 15 de dezembro de 2008].

12. STATACORP LP. Stata programming: reference manual: release 9. College Station, Tex.: StataCorp LP 2005.

13. Kemp KK. Encyclopedia of geographic information science. Los Angeles: SAGE Publications; 2008.

14. Environmental Systems Research Institute (Redlands Calif.). ArcView GIS. 3.1 for Windows. ed. Redlands, Calif.: ESRI; 1998

15. Cerbino Neto J. Fatores associados à incidência de leishmaniose visceral em Teresina-PI na década de 90 [dissertação de mestrado]. Rio de Janeiro: Faculdade de Medicina da UFRJ; 2003.

16. Câmara G, Monteiro AM, Fucks SD, Carvalho MS. Análise espacial de dados geográficos. INPE; 2001. Disponível em http://www.dpi.inpe.com.br/gilberto/ livro. [Acessado em 13 de novembro de 2007].

17. Paim JS, Silva LMV, Costa MCN, Prata PR, Lessa I. Desigualdades na situação de saúde do município de Salvador e relações com as condições de vida. Rev Ciências Médicas e Biológicas 2003; 2(1): 30-39.

18. World Health Organization. Tuberculosis control, surveillance, planning, financing. WHO Report. Geneva; 2004.

19. Vendramini SHF, Gazetta CE, Netto FC, Cury MR, Meirelles EB, Kuyumjian FG, el al. Tuberculose em município de porte médio do sudeste do Brasil: indicadores de morbidade e mortalidade, de 1985 a 2003. J Bras Pneum 2005; 31(3): 237-43.

20. Akerman M, Stephens C, Campanario P, Maia PB. Saúde e meio ambiente: uma análise de diferenciais intraurbanos enfocando o Município de São Paulo, Brasil. Rev Saúde Pública 1994; 28: 320-25. 
21. Vendramini SHF. O programa de controle da tuberculose em São José do Rio Preto-SP, 1985-2004: do contexto epidemiológico à dimensão social [tese de doutorado]. Ribeirão Preto: Escola de Enfermagem da USP; 2005.

22. Paim JS. Abordagens teórico-conceituais em estudos de condições de vida e saúde: notas para reflexão e ação. In: Barata RB. Condições de vida e situação de saúde. Rio de Janeiro: ABRASCO; 1997. p. 7-30.

23. Lima DS. Documento técnico contendo análise do sistema de informação - SINAN-TB - nos municípios prioritários, exceto a capital do estado no período de 2005 e 2006. Organização das Nações Unidas para Educação, Ciência e Cultura; Secretaria de Estado da Saúde da Paraíba, Coordenação de Vigilância Epidemiológica, Núcleo de Pneumologia Sanitária. Paraíba; 2007.

24. Figueiredo TMRM, Villa TCS, Scatena LM. et al. Desempenho da atenção básica no controle da tuberculose. Rev Saúde Pública 2009; 43(5): 825-31.

25. Oliveira AR. Avaliando as condições de acessibilidade dos doentes de tuberculose ao diagnóstico e tratamento em serviços de saúde de Campina Grande - PB [dissertação de mestrado]. João Pessoa: Programa de Pós-Graduação em Enfermagem da UFPB; 2008.
26. Ruffino Neto A. Tuberculose. Revista do Hospital das Clínicas da Faculdade de Medicina. Ribeirão Preto 1991; 24: 225-40.

27. Santos MLSG, Vendramini SHF, Gazetta CE, Oliveira SAC, Villa TCS. Pobreza: caracterização socioeconômica da tuberculose. Rev Latino-Am Enferm 2007; 15: 762-67.

28. Chiesa AM, Westphal MF, Kashiwagi NM. Geoprocessamento e a promoção da saúde: desigualdades sociais e ambientais em São Paulo. Rev Saúde Pública 2002; 36(5): 559-67.

29. Rodrigues L, Barreto M, Kramer M, Barata RCB. Resposta brasileira à tuberculose: contexto, desafios e perspectivas. Rev Saúde Pública 2007; 41(S1): 1-2.

30. Carbone MH. Tísica e rua: os dados da vida em jogo [dissertação de mestrado]. Recife: Escola Nacional de Saúde Pública; 2000. 